\title{
Combined Group I and III ABO Discrepancies in Multiple Myeloma with IgG-Lambda Type: A Case Report
}

\author{
Joonhong Park ${ }^{a}$ Dong Wook Jekarl ${ }^{a}$ Suk Young Park ${ }^{b}$ Soyoung Shin ${ }^{a}$ \\ Departments of ${ }^{\mathrm{a}}$ Laboratory Medicine and ${ }^{\mathrm{b}}$ Internal Medicine, College of Medicine, Catholic University of Korea, \\ Seoul, Republic of Korea
}

\section{Key Words}

Multiple myeloma · ABO discrepancies - Rouleau formation . Loss of isoagglutinin

\begin{abstract}
Objective: To report a case with unusual $A B O$ discrepancies caused by coexistence of the loss of anti-B isoagglutinin and rouleau formation. Clinical Presentation and Intervention: A 79-year-old female diagnosed as having multiple myeloma (MM) with monoclonal lgG- $\lambda$ type showed rouleau formation in peripheral blood smear. The $A B O$ and Rh blood type before the diagnosis of $\mathrm{MM}$ was $\mathrm{A}+$, but the following $A B O$ grouping was interpreted as $A B+$. The $A B O$ genotype revealed the subtypes $A 102$ and 0101 , which confirmed her $A B O$ phenotype as A+. Conclusion: This was a case of combined group I and III ABO discrepancies mimicking blood group AB.

(C) 2016 S. Karger AG, Basel
\end{abstract}

\section{Introduction}

The ABO blood group is the most important blood type system in human blood transfusion, which exists as 4 allelic forms of $\mathrm{AB}, \mathrm{A}, \mathrm{B}$, and $\mathrm{O}$. Notwithstanding the

\section{KARGER}

E-Mail karger@karger.com www.karger.com/mpp (c) 2016 S. Karger AG, Basel

Karger

This is an Open Access article licensed under the terms of the Creative Commons Attribution-NonCommercial 3.0 Unported license (CC BY-NC) (www.karger.com/OA-license), applicable to the online version of the article only. Distribution permitted for non-commercial purposes only. modern laboratory technologies and reagents developed, ABO discrepancies still occur, which means the unexpected pattern of antigen on the cell and the opposite antibody in the serum. ABO discrepancies may be arbitrarily divided into 4 major categories: briefly, group I is associated with unexpected reactions in the reverse typing due to weakly reacting or missing antibodies, whereas group II is associated with unexpected reactions in the forward typing due to weakly reacting or missing antigens. Group III is caused by protein or plasma abnormalities and results from rouleau formation or pseudoagglutination. Finally, group IV is due to miscellaneous problems such as polyagglutination $[1,2]$. The purpose of this report was to describe a case with unusual $A B O$ discrepancies caused by coexistence of the loss of anti-B isoagglutinin and the rouleau formation in a patient diagnosed as multiple myeloma (MM) with monoclonal gammopathy of the IgG- $\lambda$ type.

\section{Case Report}

A 79-year-old female with type 2 diabetes mellitus was admitted to Daejeon St. Mary's Hospital for the evaluation of right-sided chest pain with no associated injuries. Contrast-enhanced computed tomography revealed multiple fractures at the right 4 th to 10th ribs. In the peripheral blood smear, rouleau formation was promi- 
Table 1. Laboratory findings of our patient and reported cases showing $\mathrm{ABO}$ discrepancy in literature review

\begin{tabular}{|c|c|c|c|c|c|c|c|c|c|}
\hline $\begin{array}{l}\text { Sex/ } \\
\text { age }\end{array}$ & Diagnosis & $\begin{array}{l}\text { ABO discrepancy } \\
\text { (forward/reverse) }\end{array}$ & Discrepancy cause & $\begin{array}{l}\text { Discrepancy } \\
\text { category }\end{array}$ & $\begin{array}{l}\mathrm{ABO} \\
\text { genotype }\end{array}$ & $\begin{array}{l}\mathrm{IgG} \\
\mathrm{mg} / \mathrm{dl}\end{array}$ & $\begin{array}{l}\mathrm{IgA} \\
\mathrm{mg} / \mathrm{dl}\end{array}$ & $\begin{array}{l}\text { IgM, } \\
\mathrm{mg} / \mathrm{dl}\end{array}$ & Ref. \\
\hline $\mathrm{F} / 79$ & MM with $\operatorname{IgG}(\lambda)$ & $\mathrm{A} / \mathrm{A} \rightarrow \mathrm{AB} / \mathrm{AB}$ & $\begin{array}{l}\text { Loss of anti-B and } \\
\text { rouleau formation }\end{array}$ & $\begin{array}{l}\text { Groups I } \\
\text { and III }\end{array}$ & $\mathrm{ABO} * \mathrm{~A} / \mathrm{O}$ & 6,468 & 90 & 20.4 & $\begin{array}{l}\text { This } \\
\text { study }\end{array}$ \\
\hline $\mathrm{F} / 56$ & MM with IgG (к) & $\mathrm{A} / \mathrm{AB}$ & Loss of anti-B & Group I & n.d. & 4,970 & $<29.9$ & $<26.4$ & 3 \\
\hline $\mathrm{F} / 60$ & MM with $\lambda$ & $\mathrm{B} / \mathrm{AB}$ & Loss of anti-A & Group I & n.d. & 382.8 & $<28.5$ & $<29$ & 3 \\
\hline $\mathrm{M} / 52$ & MM with $\operatorname{IgG}(\lambda)$ & $\mathrm{B} / \mathrm{AB}$ & Loss of anti-A & Group I & n.d. & 5,243 & $<28.5$ & $<29$ & 3 \\
\hline $\mathrm{F} / 78$ & MM with IgA (к) & $\mathrm{B} / \mathrm{AB}$ & Loss of anti-A & Group I & $\mathrm{ABO} * \mathrm{~B} / \mathrm{O}$ & 236 & 4,430 & $<20$ & 4 \\
\hline $\mathrm{F} / 55$ & Liver cancer & $\mathrm{O} / \mathrm{B}$ & Loss of anti-B & Group I & $\mathrm{ABO}^{*} \mathrm{O} / \mathrm{O}$ & 63 & 65 & 12 & 6 \\
\hline $\mathrm{M} / 20$ & Common variable immunodeficiency & $\mathrm{O} / \mathrm{B}$ & Loss of anti-B & Group I & $\mathrm{ABO}^{*} \mathrm{O} / \mathrm{O}$ & 104 & $<13$ & $<15$ & 7 \\
\hline $\mathrm{M} / 16$ & Acute osteomyelitis & $\mathrm{O} / \mathrm{B}$ & Loss of anti-B & Group I & $\mathrm{ABO} * \mathrm{O} / \mathrm{O}$ & 770 & 244 & 13.5 & 8 \\
\hline
\end{tabular}

$\mathrm{MM}=$ Multiple myeloma; .d. $=$ not done.

nent. Laboratory findings showed white blood cell count of 8,500/ $\mathrm{mm}^{3}$, hemoglobin of $6.7 \mathrm{~g} / \mathrm{dl}$, platelet count of $142,000 / \mathrm{mm}^{3}, \mathrm{IgG}$ of $6,468 \mathrm{mg} / \mathrm{dl}, \mathrm{IgA}$ of $90 \mathrm{mg} / \mathrm{dl}, \mathrm{IgM}$ of $20.4 \mathrm{mg} / \mathrm{dl}$, $\kappa$ light chain of $48.26 \mathrm{mg} / \mathrm{l}$ (serum, reference $3.3-19.4$ ) and $138.36 \mathrm{mg} / \mathrm{l}$ (urine, $0-32.71$ ), $\lambda$ light chain of 1,259 $\mathrm{mg} / \mathrm{l}$ (serum, 5.71-26.30) and $1,195.40 \mathrm{mg} / \mathrm{l}$ (urine, $0-4.99$ ), blood urea nitrogen of $101.4 \mathrm{mg} / \mathrm{dl}$, and creatinine of $3.62 \mathrm{mg} / \mathrm{dl}$. Serum and urine immunofixation showed monoclonal gammopathy of the IgG- $\lambda$ type reflecting an abnormal albumin-to-globulin ratio. Patient red blood cells (RBCs) were evaluated for reactivity of the forward typing with Novaclone anti-A and anti-B murine monoclonal reagents (Dominion Biologicals Ltd., Dartmouth, N.S., Canada) and of the reverse typing with Affirmagen A1 and B RBC cell reagents (Ortho Clinical Diagnostics, Pencoed, UK). The ABO and Rh blood type before the diagnosis of $\mathrm{MM}$ had been $\mathrm{A}+$ in previous medical records, but the following $\mathrm{ABO}$ grouping showed $\mathrm{A}+$ in red cells but not anti-B in serum by a conventional tube test. A repeated $\mathrm{ABO}$ test by the microtube column agglutination technique using the Diamed-ID LISS/Coombs gel card containing anti-IgG and anti-C3d within the gel matrix (DiaMed GmbH, Cressier, Switzerland) was interpreted as $\mathrm{AB}+$ (the forward type: A cell $4+, \mathrm{B}$ cell $2+$; the reverse type: absence of anti-A and anti-B). They were negative for both Coombs test and irregular antibody screening. To resolve this ABO discrepancy, the regions containing coding sequences of exons 6 and 7 in the $A B O$ gene were directly sequenced on an ABI 3130XL Genetic Analyzer (Applied Biosystems, Foster City, Calif., USA). The $A B O$ genotype contained the subtypes $A 102$ and 0101 ; thus, her ABO phenotype was confirmed to be $A+$. She received several units of $\mathrm{A}+$ packed $\mathrm{RBC}$ transfusion without complication, undergoing the conservative treatment due to her old age.

\section{Discussion}

This was a case of combined group I and III ABO discrepancy caused by coexistence of the loss of anti-B isoagglutinin and the rouleau formation in MM with monoclonal gammopathy of the IgG- $\lambda$ type. Several Korean cases had been reported with MM $[3,4]$ or with other diseases [5-8] about group I ABO discrepancies due to the loss of isoagglutinins only (table 1). An ABO incompatibility reaction such as acute hemolytic reaction or fatal complication can occur in our patient if she receives the wrong type of $\mathrm{AB}+\mathrm{RBC}$ transfusion instead of true type A+.

$\mathrm{M}$ protein produced by $\mathrm{MM}$ cells is a common cause of group III ABO discrepancies resulting from elevated levels of globulin. Abnormally elevated paraproteins cause the rouleau formation which is stacks or aggregations of RBCs due to reduction in 'zeta potential' (charge on RBC membrane) [2]. It could be mistaken for agglutination by medical technicians in the forward grouping. The washing technique rids the RBC membranes of the paraproteins and frees the RBCs in the case of rouleau formation in the reverse grouping. In true agglutination, red cells will continue to clump after washing with normal saline [3].

Meanwhile, group I ABO discrepancies can also occur when patients have depressed antibody production or cannot produce the ABO antibodies. Weak agglutination reactions may be obtained with reagent $\mathrm{RBC}$ cells and are a result of weak expression of anti-A and anti-B in the serum. Group I ABO discrepancy should be suspected because $\mathrm{RBC}$ and serum grouping reactions are normally very strong. IgM is the predominant isotype found in blood group A or B individuals, although small quantities of IgG antibody can be detected. In blood group $\mathrm{O}$ serum IgG is the major isotype for anti-A and anti-B [2]. Therefore, the severe deficiency of IgM would be responsible for group I ABO discrepancies in MM with blood group A or B [2]. 
Recently, Kaur et al. [9] reported that a few $(0.06 \%$, $28 / 44,425)$ blood group discrepancies were observed in 44,425 blood groups. Among them, 20 subgroups of A and $\mathrm{B}$ were a main sample-related problem of $\mathrm{ABO}$ discrepancies. In order to resolve the ABO discrepancy and to provide compatible blood for transfusion, it is necessary to obtain relevant historical information from the patient and to provide medical and technical expertise as well as education for the blood bank technologist in transfusion medicine-related testing, practice, risks, and related areas [2]. ABO genotyping can also be done with a high level of accuracy for the resolution of $\mathrm{ABO}$ serological discrepancies [10].

\section{Conclusion}

This was a case of combined group I and III ABO discrepancies mimicking blood group $\mathrm{AB}$ in $\mathrm{MM}$ with monoclonal IgG- $\lambda$ type. ABO genotyping was very useful to resolve this unusual $\mathrm{ABO}$ discrepancy.

\section{Disclosure Statement}

There is no conflict of interest.

\section{References}

1 Harmening DM: The ABO blood group system; in Harmening DM (ed): Modern Blood Banking and Transfusion Practices, ed 6. Philadelphia, Davis Co, 2012, pp 136-148.

2 Roback JD, Combs MR, Grossman BJ, et al (eds): Technical Manual, ed 17. Bethesda, American Association of Blood Banks (AABB), 2011. http://www.aabb.org/.

3 Ha JS, Kim EJ, Chun HJ, et al: Three cases of multiple myeloma showing $\mathrm{ABO}$ discrepancy. Korean J Blood Transfus 1998;9:289-293.
4 Kim SY, Oh SH, Park KS, et al: ABO discrepancy in an elderly patient with IgA kappa-type multiple myeloma. Ann Hematol 2010;89: 747-748.

5 Park TS, Oh SH, Choi JC, et al: A case of agammaglobulinemia detected by $\mathrm{ABO}$ discrepancy in a 13-year-old girl. Korean J Lab Med 2002;22:364-366.

6 Suh IB, Chang EA, Kim HJ, et al: Two cases of $\mathrm{ABO}$ discrepancy due to hypogammaglobulinemia. Korean J Blood Transfus 2003;14: 240-245.

7 Oh SH, Kang CI, Kim J, et al: ABO discrepancy in a young Korean serviceman with common variable immunodeficiency. Ann Hematol 2010;89:629-630.
8 Jung CL, Cha MK, Jun BH, et al: A case of IgM deficiency with $\mathrm{B}$ cell deficiency detected by $\mathrm{ABO}$ discrepancy in a patient with acute osteomyelitis. Ann Lab Med 2013;33:208-211.

9 Kaur G, Kaur P, Basu S, et al: Blood group discrepancies at a tertiary care centre - analysis and resolution. Int J Lab Hematol 2014;36: 481-487.

10 Anstee DJ: Red cell genotyping and the future of pretransfusion testing. Blood 2009;114: 248-256. 